\title{
Assessment of Economic Efficiency by Life Cycle Stages
}

\author{
Anton Vladimirovich Chepulyanis*, Irina Evgenievna Vlasova
}

\author{
Ural State Economic University Yekaterinburg, Russia \\ ${ }^{*}$ Corresponding author.Email:anthonas@yandex.ru
}

\begin{abstract}
The article presents the theoretical and organizational and methodological aspects of the analysis of economic efficiency at the tactical and strategic levels. On the basis of the literature review, the main directions of the interpretation of the definition of "economic efficiency" are highlighted, the author's definition of this category and its classification are given. The differences between the concepts of "efficiency and effectiveness" are determined. The system of indicators of the current and strategic efficiency of economic activity is considered, their brief description is given. The concept of the full effectiveness cycle and the features of the analysis of strategic efficiency by stages of the life cycle are presented. The features of assessing the effectiveness of economic activity with negative performance are disclosed.
\end{abstract}

Keywords: economic efficiency, strategic efficiency, efficiency by stages of the life cycle

\section{INTRODUCTION}

Management of economic efficiency at all stages of the life cycle of the market circulation of a product or the company as a whole is the most difficult process, since at each stage and even stage there are moments when it is extremely difficult to maintain and maintain efficiency at an acceptable level due to the specifics of the technological process, organizational structure , management principles and other nuances of management. Therefore, it becomes necessary to introduce management technologies that allow implementing the principles of a quality management system, the goal of which is a full cycle of efficiency throughout the entire life cycle of a product or the company as a whole.

\section{THE ESSENCE OF ECONOMIC EFFICIENCY}

Economic efficiency is a complex category that permeates all stages of social production. In economics, the concept of "production efficiency" was formed at the end of the 20s of the XX century. and received the greatest development in the late $50 \mathrm{~s}$ and in the first half of the $60 \mathrm{~s}$. Currently, the theory of efficiency is developing in various aspects, which are reflected in the works of leading economists in all directions (table 1).
At the same time, it is necessary to separate the concepts of efficiency and effectiveness. They are closely related.

Economic performance is understood as a subjective assessment of the quality of changes in financial and nonfinancial parameters of management, characterizing the economic potential and economic results of an economic entity, the level of its sustainable development and the ability to position itself and its product on the market.

In turn, by the efficiency of economic activity, we mean a set of indicators that give a relative (qualitative) assessment of the effectiveness (achieved positive effect) of the use of material and intangible resources of the company, reflecting the sustainable growth of the welfare and economic potential of the organization, as well as the efficiency and rationality of the management decisions in various areas of management at all stages and stages of the life cycle (market circulation).

One of the key tasks of strategic management is the implementation of the concept of a full effectiveness cycle of business processes at all stages and stages of market circulation. At the same time, to ols for strategic (long-term) assessment of the quality and efficiency of economic activities are needed, such as functional cost analysis (process-oriented strategic analysis), integrated business planning, performance monitoring through the development and implementation of a KPI system, business consolidation, etc. 
Table 1. Key directions in the disclosure of the concept "Economic efficiency"

\begin{tabular}{|c|c|}
\hline Authors & Content \\
\hline $\begin{array}{l}\text { V. N. Koporulin's New } \\
\text { Economic Dictionary, } \\
\text { D. V. Ostapenko }\end{array}$ & $\begin{array}{l}\text { Economic efficiency is the effectiveness of economic activity, economic programs and } \\
\text { measures, characterized by the ratio of the obtained economic effect (result) to the costs } \\
\text { of factors, resources, which led to the receipt of this result; achieving the greatest volume } \\
\text { of production using the available limited amount of resources or ensuring a given output } \\
\text { at the lowest cost ... }\end{array}$ \\
\hline Big economic encyclopedia & $\begin{array}{l}\text { The concept of "economic efficiency" is used in order to provide a general assessment of } \\
\text { the effectiveness (efficiency) of social production. An efficient state of the economy is one } \\
\text { in which the needs of consumers are satisfied to the maximum extent, provided that } \\
\text { resources are limited. ... }\end{array}$ \\
\hline A. Thomson & $\begin{array}{l}\text { Efficiency is the ratio between the number of sources for production used by the } \\
\text { enterprise and the quality of the goods produced using these sources. ... }\end{array}$ \\
\hline D. North & $\begin{array}{l}\text { Efficiency is a system that reproduces the conditions of economic growth, since only } \\
\text { economic growth contributes to an increase in welfare (wealth) ... }\end{array}$ \\
\hline V. Pareto & $\begin{array}{l}\text { Efficiency - the state of the system, in which there is no way to improve the state of any } \\
\text { of its elements, so as not to worsen its other elements ... }\end{array}$ \\
\hline Lapygin Yu. N. & $\begin{array}{l}\text { Characteristics of processes and impacts of a managerial orientation, which primarily } \\
\text { reflects the degree of achievement of the goals pursued and is defined as the ratio of the } \\
\text { result of the organization's activities to the costs aimed at achieving it ... }\end{array}$ \\
\hline I. V. Sharova & $\begin{array}{l}\text { "Efficiency" is interpreted as the relative effect, the effectiveness of the process, } \\
\text { operation, project, defined as the ratio of the effect (result) to the costs, expenses that } \\
\text { caused or ensured its receipt. } \\
\text { Economic efficiency is an indicator or a set of indicators characterizing the effectiveness } \\
\text { of decisions made in various areas of the functioning of material production or the service } \\
\text { sector, which consists in saving (reducing consumption) of various types of resources, } \\
\text { estimated in value terms when comparing the existing and newly created process options } \\
\text { (operations, procedures, functions, systems). }\end{array}$ \\
\hline O. P. Strakhova & $\begin{array}{l}\text { Efficiency is the ability of a system (not only an economic system, but also another, } \\
\text { technical, social) in the process of its functioning to produce an economic effect (potential } \\
\text { efficiency) and the actual creation of such an effect (actual efficiency). }\end{array}$ \\
\hline Ryzhkova T.V., Gorelova L.V. & $\begin{array}{l}\text { Qualitative category associated with the intensity of the enterprise; reflects the deep } \\
\text { processes of improvement occurring in all its elements, and excludes mechanistic } \\
\text { approaches, both to its understanding and to the assessment ... }\end{array}$ \\
\hline Chizhova E.N. & $\begin{array}{l}\text { Efficiency is the relationship of scientific, technical, socio-ecological and economic } \\
\text { effects, each of which ... characterizes the result of economic activity only according to } \\
\text { the relevant criteria and indicators ... }\end{array}$ \\
\hline
\end{tabular}

All these methods and tools will underlie the mechanism for ensuring the economic efficiency of the enterprise (MOEEP), which should ensure sustainable development and the continuity of the enterprise. Approaches to the formation of MOEEP are determined by technical and technological parameters of production, macro- and microeconomic, socio-cultural, market (sectoral) features of management and positioning of the organization.

The concept of the full effectiveness cycle is based on a spatio-temporal approach to assessing effectiveness both in the current (operational) mode and in the long term. For this purpose, we distinguish the following types of efficiency.

"Static efficiency is the main form of assessment in the short term, when current (operational) issues are being resolved, excluding capital investments (investments) in the expansion of production capacities and changes in the scale of activities.

Dynamic efficiencyinvolves a qualitative assessment of financial and non-financial results of economic activity due to flexible variation in resources and significant changes in the organizational and technical level of the enterprise in the strategic plan. Dynamic efficiency is the main way to maintain a high competitiveness and position an organization over the long term"... (Chizhova, E.N. Theory and methodology of rationalizing the activities of an industrial enterprise: author. diss. ... doc. econom. Sciences: 08.00.05. BelSTU, Belgorod, 2004 - 689 p.)

The concept of a full cycle of effectiveness includes an assessment of efficiency both in the internal environment (assessment of the effectiveness of internal business processes, the economic potential of the organization) and in the external (assessment of market potential).

"Internal efficiency reflects the assessment of the obtained effect of the enterprise from the activities of the enterprise on the basis of the ratio of indicators of economic potential (expended resources, attracted funds) and performance. 


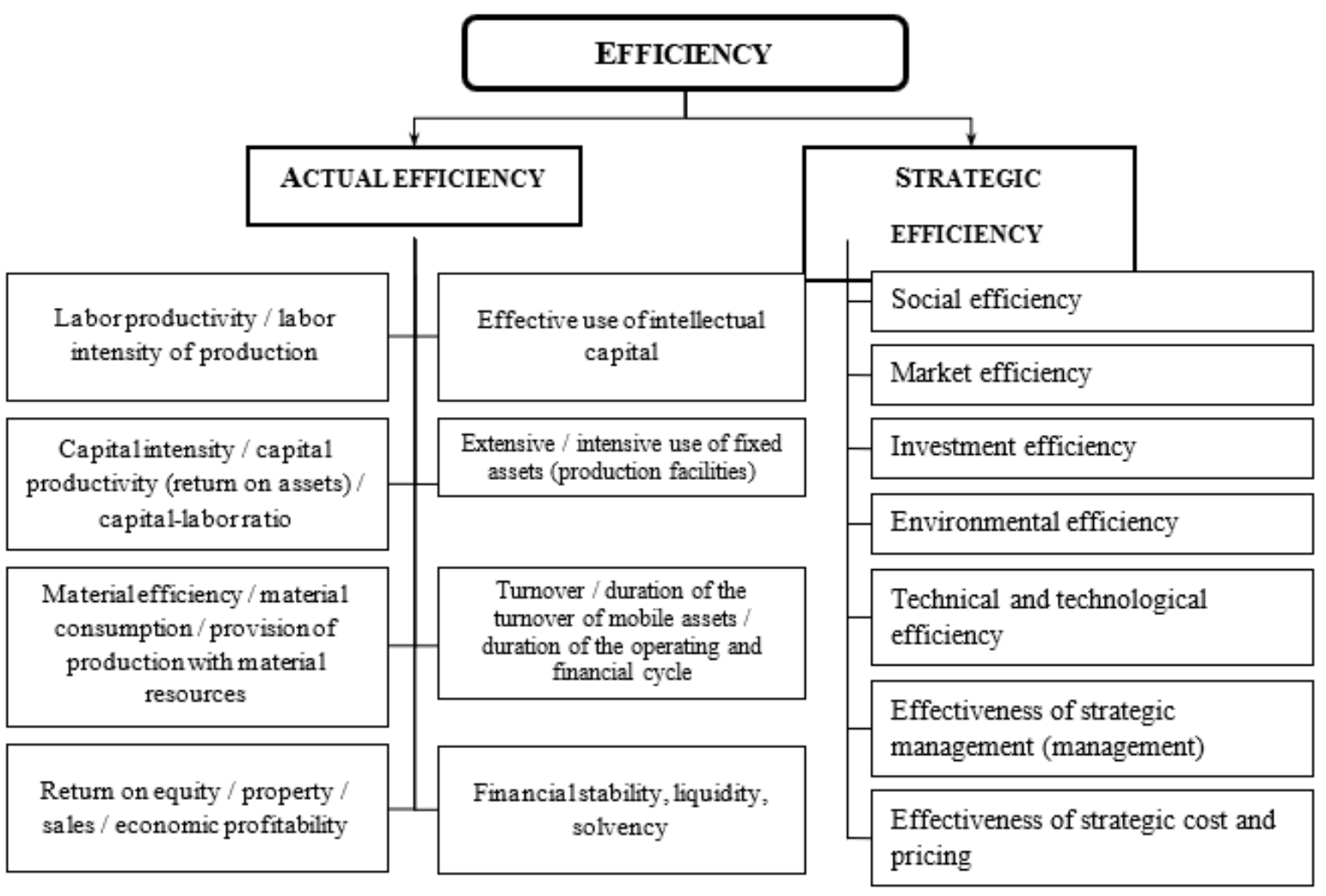

Figure 1 System of performance indicators from the point of view strategic management

External efficiency reflects the structure of social needs and the degree of their satisfaction by the enterprise, the level of utility and value characteristics (attributes) for the consumer of the manufactured product, the company's share in the industry (market) and its potential opportunities and threats to positioning and competitiveness"... [Romanova O. Optimization of enterprise behavior in modern conditions / O. Romanova // Problems of theory and practice of management. 2002. - No. 3. - P. 116-123.]

From the point of view of compliance of efficiency with the parameters of the company's strategy, strategic and actual (integral) efficiency are highlighted.

Actual (integral) efficiency represents the existing (achieved at the time of the analysis) the ratio of spent or available material and non-material resources to performance indicators, taking into account the strategic parameters of the organization's functioning.

Strategic efficiency implies a qualitative assessment of the results achieved in the implementation of the company's mission and strategy on a wide range of issues of technological progress, sustainable development (technical and technological, social, environmental, economic) and positioning of the organization in the industry (market) in the long term.

\section{STRATEGIC EFFECTIVENESS}

Strategic efficiency includes a system of indicators, which together form a general idea of the level of rationality of the choice of a particular strategic scenario. The grouping and systematization of strategic performance indicators and their characteristics are presented in Table 2.

The strategic efficiency model is shown in Figure 2. As can be seen from the model, the sources of strategic efficiency are tangible and intangible resources for the implementation of the company's strategy and mission, a reliable information support system for strategic management, as well as internal and external conditions (strategic parameters) of management, taking into account uncertainty and risk.

Strategic efficiency is primarily due to the effectiveness of the chosen strategy, which in turn determines the strategic parameters and conditions for effective management in the long term. As a result, according to general and specific indicators of strategic efficiency, we can determine, in general, the effectiveness of the implementation of the strategic scenario for the development of an economic entity.

Strategic analysis of efficiency must be carried out at all stages and stages of the product life cycle, which 


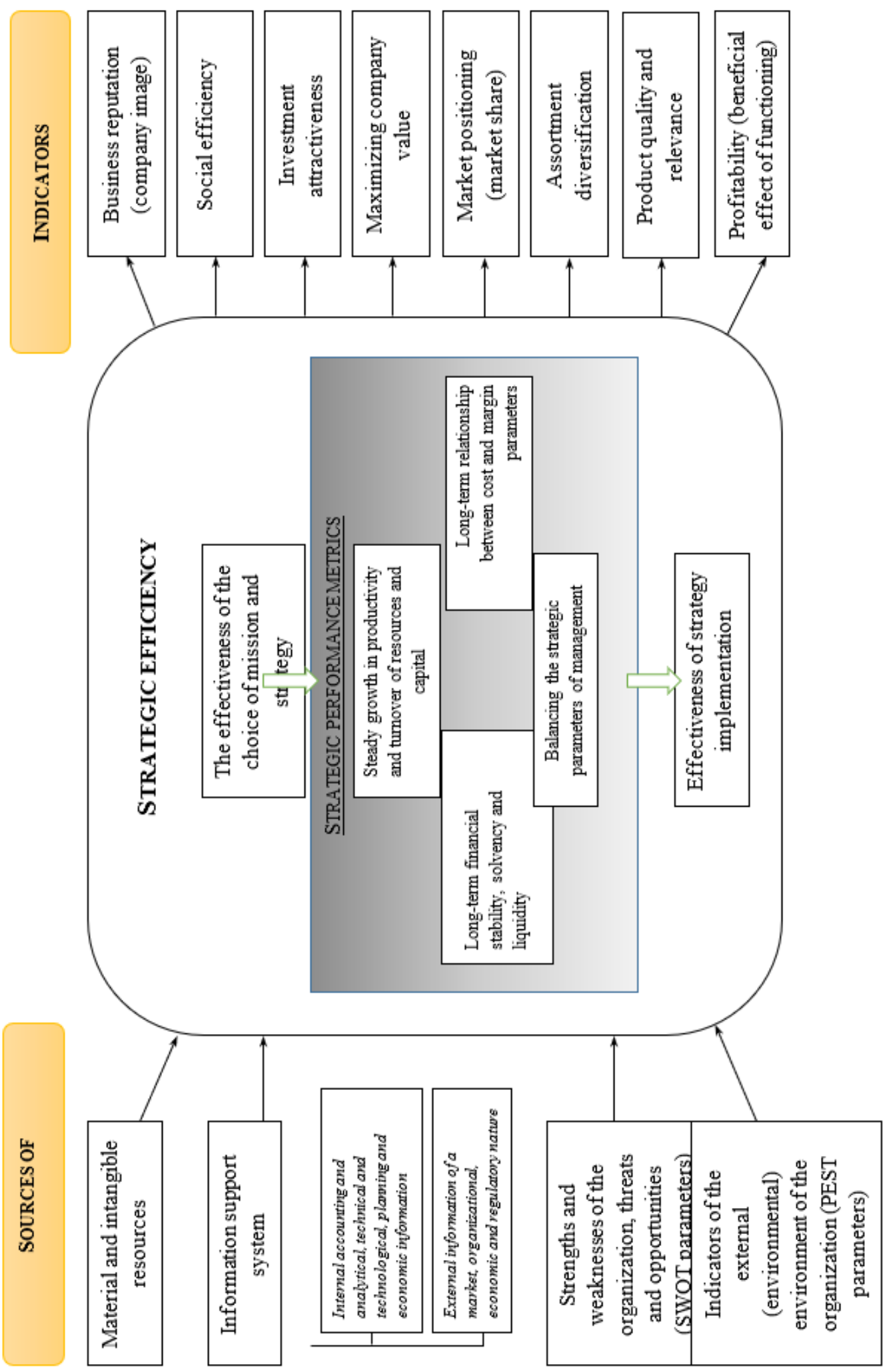

Figure 2 Strategic effectiveness

allows you to create a continuous process of management and analytical assurance of efficiency throughout the entire period of market circulation of a product from the moment of R\&D and development of a new product to its withdrawal from production and its removal from service. Analysis of efficiency at each stage of the life cycle has its own nuances and characteristics, as well as a system of specific indicators (Table 3 ). 
Table 2. Indicators of strategic efficiency

\begin{tabular}{|c|c|}
\hline $\begin{array}{c}\text { General } \\
\text { indicators }\end{array}$ & Private indicators \\
\hline Company image & $\begin{array}{l}\text { Company reputation - subjective assessment by external users (customers, partners, personnel, } \\
\text { government, financial institutions, etc.) of the performance indicators of an economic entity and its } \\
\text { impact on the external (environment) environment. } \\
\text { Brand (trade mark)- recognition and public perception of the means of individualization of an economic } \\
\text { entity. The assessment is carried out on the basis of a comparison of the costs and resources invested in } \\
\text { brand promotion and performance indicators. }\end{array}$ \\
\hline Social efficiency & $\begin{array}{l}\text { Availability and scope of a social package for company personnel - the level of social and material } \\
\text { support for employees and their families, the provision of social benefits and opportunities for the } \\
\text { implementation of the creative and intellectual capital of the personnel. } \\
\text { Rationalization level - the level of interest and initiative of employees in improving production and } \\
\text { organizational processes, increasing the effectiveness and efficiency of business processes, a system of } \\
\text { incentives (motivation) for innovation. } \\
\text { Personnel loyalty to the company- acceptance and perception of the initiatives of the company's } \\
\text { management on the part of the personnel, as well as the readiness to promptly implement the assigned } \\
\text { tasks; matching personnel expectations and reality; psychological climate at the enterprise. } \\
\text { Indicators of the presence and movement of personnel: the level of staff turnover, constancy, staff } \\
\text { turnover. } \\
\text { The quality of labor resources: the level of competence of employees and their correspondence to the } \\
\text { qualifications of the functions performed, the gender and age composition of the personnel, the } \\
\text { correspondence of the growth rates of wages and labor productivity. }\end{array}$ \\
\hline $\begin{array}{l}\text { Investment } \\
\text { attractiveness }\end{array}$ & $\begin{array}{l}\text { Capital multiplier - the ratio of equity and borrowed capital, the level of capitalization, the possibility } \\
\text { of self-financing of economic activity. } \\
\text { Investor characteristics: the number and diversification of investors, the presence of foreign investors, } \\
\text { the participation of the state (public-private partnership). } \\
\text { The organization's ability to attract new and retain old investors: system of bonuses and incentives for } \\
\text { investors, the level and time of return on invested capital }\end{array}$ \\
\hline $\begin{array}{l}\text { Maximizing } \\
\text { company value }\end{array}$ & $\begin{array}{l}\text { Sales volume (gross revenue) and its sufficiency for the formation of positive performance in all types } \\
\text { of activities and at all stages of the product life cycle; } \\
\text { Stable positive dynamics of the value of property (assets) and capital of the organization; } \\
\text { Long-term compliance with the balance of accounts receivable and payable; } \\
\text { Nominal and market value of shares on the RCB, opportunities for the company's capitalization; } \\
\text { The cost of production capacity (fixed assets and material and technical base) and intellectual capital; } \\
\text { The presence or absence of own working capital; } \\
\text { Positive rating assessment of financial condition, cash (financial flows) and financial performance. }\end{array}$ \\
\hline $\begin{array}{l}\text { Market } \\
\text { positioning }\end{array}$ & $\begin{array}{l}\text { Market share - the share of the company's products on the market, determined by the volume of sales } \\
\text { (in comparison with competitors), the degree of coverage of consumers, the degree of distribution of } \\
\text { the assortment by market segments, etc. } \\
\text { Diversification of sales markets - expansion of the sphere of influence and presence of the company's } \\
\text { product in various market segments, the company's ability to implement several product strategies in } \\
\text { several market segments. } \\
\text { The scale of the influence of market forces on the indicators of the organization's economic activity - } \\
\text { how effectively the company implements the policy of overcoming the influence of market forces on } \\
\text { its competitive positions and positioning }\end{array}$ \\
\hline $\begin{array}{l}\text { Product } \\
\text { characteristics }\end{array}$ & $\begin{array}{l}\text { Diversification of the product portfolio - the degree of diversity of the assortment nomenclature for } \\
\text { greater coverage of different consumer groups and market segments } \\
\text { Product quality - a set of properties and characteristics of a product that determine its suitability to } \\
\text { meet certain needs in accordance with its purpose, as well as technical, economic, psychosensory, } \\
\text { aesthetic, ergonomic and other requirements for the product. } \\
\text { Attribute matching (value characteristics) of the product to consumer demand, the degree of consumer } \\
\text { satisfaction with the quality of the product and its compliance with the criteria for usefulness. }\end{array}$ \\
\hline Profitability & $\begin{array}{l}\text { Economic profitability (return on equity) - taking into account the strategy of maximizing the } \\
\text { company's value, the growth rate of performance indicators should exceed the dynamics of the cost of } \\
\text { capital and property of the organization, which will ensure a steady growth of this indicator and the } \\
\text { long-term efficiency of using resources and sources of their formation. } \\
\text { Return on sales- an indicator of the effectiveness of the main statutory activities of the organization; } \\
\text { the excess of the growth rate of financial results from the main activity over the dynamics of trade } \\
\text { turnover ensures the long-term efficiency of economic activity as a whole } \\
\text { Operating leverage- an indicator that reflects the effectiveness of managing the profitability and break- } \\
\text { even performance of the organization; a stable decrease in the indicator guarantees the long-term } \\
\text { effectiveness of the implemented cost and pricing strategy at the enterprise. }\end{array}$ \\
\hline
\end{tabular}




\section{FEATURES OF ASSESSING ECONOMIC EFFICIENCY IN CASE OF NEGATIVE PERFORMANCE}

Summarizing the above, in this study we have built an "ideal", from our point of view, a theoretical model of strategic and current business performance. The

Table 3. Analysis of efficiency by stages of the life cycle

\begin{tabular}{|c|c|c|}
\hline $\begin{array}{l}\text { Stage / stage } \\
\text { name } \\
\text { product life } \\
\text { cycle } \\
\end{array}$ & $\begin{array}{l}\text { Goals and objectives of economic efficiency } \\
\text { analysis }\end{array}$ & Performance indicators \\
\hline \multicolumn{3}{|c|}{ PRE-PRODUCTION STAGE } \\
\hline Research phase & $\begin{array}{l}\text { The goal is to determine the efficiency and return of } \\
\text { costs and resources for ongoing marketing research } \\
\text { and R\&D. } \\
\text { The task of analytical support at this stage is to } \\
\text { determine the effectiveness and possibilities of } \\
\text { introducing technical innovations and the choice of } \\
\text { the most effective production scenario and its } \\
\text { technical and technological equipment, a strategy } \\
\text { for positioning a new product on the market. The } \\
\text { choice should be based on: } \\
\text { - on the assessment of the cost intensity of } \\
\text { the production technology, which would ensure the } \\
\text { highest level of product quality and the compliance } \\
\text { of its physical characteristics with consumer needs; } \\
- \\
\text { new product to the market and expanding the range } \\
\text { to satisfy different groups of consumers and } \\
\text { comparing it with the expected external result. } \\
\text { At this stage, the most capital-intensive costs are } \\
\text { carried out and it is necessary to ensure the } \\
\text { maximum level of positive material and non- } \\
\text { material results from the measures taken. }\end{array}$ & $\begin{array}{l}\text { Technical and economic efficiency of the } \\
\text { introduced sample (technology) } \\
\qquad \exists=\frac{T_{\Sigma}}{C_{\Sigma}} \\
\text { where } \mathrm{T} \Sigma \text { is an integral technical indicator equal } \\
\text { to } \\
\qquad T_{\Sigma}=\prod_{i=1}^{n} T_{i}^{k_{i}} \\
\text { where Ti is a particular technical indicator, ki is } \\
\text { the weighting coefficient of the } \mathrm{i} \text {-th particular } \\
\text { indicator) }\left(151 \sum=\mathrm{i}=\mathrm{ik}\right) \\
\mathrm{C} \Sigma \text { - integral cost indicator }(\mathrm{C} \Sigma=\mathrm{K}+3+\mathrm{y}+\mathrm{P} \text {, } \\
\text { where } \mathrm{K} \text { - one-time capital costs (for acquisition, } \\
\text { transportation, installation, as well as associated } \\
\text { costs), } 3 \text { - operating costs for the entire operation } \\
\text { time of the product (technology), } \mathrm{Y} \text { is the total } \\
\text { amount of damage from failures, } \mathrm{P} \text { is the } \\
\text { accompanying positive results of using a new } \\
\text { product (technology)) ... }{ }^{1} \\
\text { IED efficiency index in conducting and }\end{array}$ \\
\hline $\begin{array}{l}\text { Development } \\
\text { and design } \\
\text { phase }\end{array}$ & $\begin{array}{l}\text { At this stage, the quality of developments and the } \\
\text { compliance of the project with the parameters and } \\
\text { results laid down in the previous stage are assessed. } \\
\text { The effect at this stage is the observance of the ratio } \\
\text { of costs (investments) in the project and the } \\
\text { potential effect of its implementation, as well as the } \\
\text { terms of implementation and recoupment of the } \\
\text { project. }\end{array}$ & $\begin{array}{l}\text { implementing R\&D } \\
\qquad И Э_{\mathrm{P}}=\frac{\ni_{И}}{\sum_{t} \frac{3_{t}+K_{t}}{(1+E)^{t-t_{\mathrm{b}}}}}+1 \\
\text { where EI is the net discounted income from the } \\
\text { conduct and implementation of R\&D results at } \\
\text { their various stages; } \\
3 t \text { is the cost of scientific development in the t-th }\end{array}$ \\
\hline $\begin{array}{l}\text { Stage of } \\
\text { approbation and } \\
\text { production of } \\
\text { prototypes }\end{array}$ & $\begin{array}{l}\text { The effectiveness of the new product will lie in its } \\
\text { innovativeness and the degree of compliance of the } \\
\text { prototypes obtained with the input parameters of } \\
\text { development and research, the absence of } \\
\text { significant comments from the test group. It also } \\
\text { estimates the amount of additional costs for } \\
\text { finalizing the product to a state suitable for } \\
\text { launching it into mass production and putting it into } \\
\text { market circulation. }\end{array}$ & $\begin{array}{l}\text { year of the billing period; Kt - capital investments } \\
\text { associated with the introduction of research and } \\
\text { development; tБ - basic moment of time; E - } \\
\text { discount rate } \\
\text { Integral effect, taking into account the likelihood } \\
\text { of successful implementation of R\&D } \\
\text { Economic efficiency of marketing research costs } \\
\text { (the expected return of marketing costs to the } \\
\text { expected net cash flow) } \\
\text { Valuing Marketing Information } \\
\text { Expert (probabilistic) assessment of the } \\
\text { effectiveness of marketing research } \\
\text { Expected payback period of R\&D taking into } \\
\text { account the value of the discounted cash flow. } \\
\text { Relative cost-effectiveness of innovation costs } \\
\text { R\&D cost animation } \\
\text { (R\&D multiplier): } \\
\text { Multi research work= } \\
\text { new product development costs/ capital } \\
\text { investments for the production and sale of the } \\
\text { product }\end{array}$ \\
\hline
\end{tabular}


Table 3. Continued.

\begin{tabular}{|c|c|c|}
\hline \multicolumn{3}{|c|}{$\begin{array}{l}\text { PRODUCTION STAGE } \\
\end{array}$} \\
\hline $\begin{array}{l}\text { Preparation stage } \\
\text { for serial } \\
\text { production }\end{array}$ & $\begin{array}{l}\text { The purpose of production preparation is to create } \\
\text { technical, organizational and economic conditions that } \\
\text { fully guarantee the transfer of the production process } \\
\text { to a higher technical and socio-economic level based } \\
\text { on technical progress, the use of various innovations } \\
\text { to ensure the efficient operation of the enterprise. }\end{array}$ & \multirow{4}{*}{$\begin{array}{l}\text { Business activity indicators that determine the turnover and } \\
\text { circulation period of resources in the operating and financial } \\
\text { cycle; The level of technical equipment of production; The } \\
\text { level of innovation of technical and technological equipment } \\
\text { of production; Defective rate in production; Indicators for } \\
\text { assessing product quality (attributive (value) indicators, } \\
\text { indicators of product reliability, manufacturability, } \\
\text { ergonomics, efficiency, environmental friendliness, energy } \\
\text { efficiency, safety, etc.) Market and marketing indicators of } \\
\text { the organization, determining the pace of promotion } \\
\text { (expansion in the market), the level of competitiveness of the } \\
\text { product, the elasticity of supply and demand for the product, } \\
\text { benchmarking, analysis of the effectiveness of market } \\
\text { strategy according to the General Electric / McKinsey } \\
\text { Matrix. Indicators of the dynamics of commodity turnover as } \\
\text { a whole, by distribution channels, assortment groups, market } \\
\text { segments (xyz-analysis of the assortment) and their } \\
\text { comparison with the dynamics of cost-formation parameters; } \\
\text { CVP analysis (margin analysis of sales) Production } \\
\text { assortment indicator: K assortment= the actual output of the } \\
\text { product range within the limits in the plan/ planned output of } \\
\text { products according to the assortmentEvaluation of the } \\
\text { effectiveness of assortment policy using the matrix method } \\
\text { of the Boston Consulting Group. }\end{array}$} \\
\hline $\begin{array}{l}\text { Product } \\
\text { expansion stage, } \\
\text { search for a } \\
\text { market niche }\end{array}$ & $\begin{array}{l}\text { The analysis of efficiency at this stage assesses the rate } \\
\text { of increase in the volume (expansion) of sales, an } \\
\text { assessment of the potential, structure and capacity of } \\
\text { the market is given. The foreground is the indicators } \\
\text { of business activity, which affect the overall efficiency } \\
\text { of the organization's business. }\end{array}$ & \\
\hline $\begin{array}{l}\text { The stage of } \\
\text { expanding sales } \\
\text { markets and } \\
\text { diversifying the } \\
\text { assortment }\end{array}$ & $\begin{array}{l}\text { At this stage, the coefficient of assortment of output } \\
\text { and sales is assessed, the level of diversification of the } \\
\text { product portfolio is analyzed, the analysis of indicators } \\
\text { of business activity and profitability of sales by } \\
\text { distribution channels, the analysis of the level, a } \\
\text { characteristic of the satisfaction of various groups of } \\
\text { consumers with the product is given. }\end{array}$ & \\
\hline $\begin{array}{l}\text { Stage of product } \\
\text { maturity } \\
\text { (maintaining } \\
\text { competitive } \\
\text { positions in the } \\
\text { market) }\end{array}$ & $\begin{array}{l}\text { Analysis of the product portfolio using the method of } \\
\text { the Boston Consulting Group Matrix, identification of } \\
\text { SCU leaders with high potential for sales growth and } \\
\text { SCU outsiders for which it is necessary to make a } \\
\text { decision to withdraw them from market circulation. } \\
\text { For SCU sales leaders, it is necessary to analyze and } \\
\text { identify growth drivers. At this stage, the effectiveness } \\
\text { of the measures taken to stimulate sales and } \\
\text { consolidate the competitive position of the product in } \\
\text { the market is analyzed. }\end{array}$ & \\
\hline \multicolumn{3}{|c|}{ POST-PRODUCTION STAGE } \\
\hline $\begin{array}{l}\text { Stage of decline } \\
\text { in sales } \\
\text { (reduction of } \\
\text { market share) }\end{array}$ & $\begin{array}{l}\text { At this stage, it is necessary to monitor the dynamics } \\
\text { of profitability and indicators of business activity, how } \\
\text { these indicators affect the overall financial stability } \\
\text { and economic potential of the organization. It is also } \\
\text { necessary to provide a comparison of the current costs } \\
\text { of maintaining the market circulation of the product } \\
\text { and the effect of removing the old product and making } \\
\text { a decision to modernize it or launch the development } \\
\text { of a completely new product (to enter a new life cycle). }\end{array}$ & $\begin{array}{l}\text { Indicators of business activity. Indicators for assessing } \\
\text { financial stability and predicting insolvency (bankruptcy) of } \\
\text { an economic entity Analyzing the effectiveness of hedging } \\
\text { and provisioning. The ratio of the costs invested in } \\
\text { maintaining the release, market circulation and after-sales } \\
\text { service of the product, with the discounted net cash flow } \\
\text { from its sale. Experience curve analysis. }\end{array}$ \\
\hline $\begin{array}{l}\text { Phase of product } \\
\text { withdrawal from } \\
\text { production } \\
\text { (curtailment) }\end{array}$ & $\begin{array}{l}\text { The purpose of analytical support at this stage of the } \\
\text { life cycle is to minimize the negative economic effect } \\
\text { of withdrawing a product from market circulation and } \\
\text { curtailing mass (batch) production. If there is a system } \\
\text { of reserve (hedging) losses of the post-production } \\
\text { stage, assess the adequacy of the formed reserves for } \\
\text { the program for curtailing production and withdrawing } \\
\text { the product from the market. Here, the analysis of the } \\
\text { ratio of costs and economic results (losses / benefits) } \\
\text { from the measures taken is carried out, the profitability } \\
\text { and cost-effectiveness of these measures is assessed. }\end{array}$ & \\
\hline $\begin{array}{l}\text { Stage of } \\
\text { termination of } \\
\text { customer service } \\
\text { support }\end{array}$ & $\begin{array}{l}\text { Analytical support allows you to give an answer about } \\
\text { the advisability of further service maintenance of the } \\
\text { product, the economic and reputational effects are } \\
\text { compared with the costs of after-sales service, in the } \\
\text { event of a significant imbalance, it is necessary to } \\
\text { make a decision to stop further service of the product. } \\
\text { At the same time, it is necessary to assess the reaction } \\
\text { of consumers to the termination of service support and } \\
\text { the expected losses from such a decision. }\end{array}$ & \\
\hline
\end{tabular}

generally accepted basic approach in this case is based on the unconditional condition of the positive performance of the business for the period: the net profit for the period should be greater than 0 (have a positive value), and the company's capital (net assets) should tend to grow steadily. At the same time, in fact, significant negative fluctuations in net profit for the period and a significant decrease in capital at the end of the reporting year are possible. Of course, it is assumed that the management of the company continuously monitors the situation, takes adequate measures, adjusts tactical steps in order to achieve the tactical and strategic goals of the company to stabilize the performance of economic activities and increase capital (net assets). Thus, every effort is made to ensure the continuity of the company and maintain the interest of stakeholders in the current circumstances. 
Table 6. Qualitative analysis of signs of "poor" actual performance

\begin{tabular}{|c|c|c|c|}
\hline I. & Financial signs: & Well no & A comment \\
\hline 1. & $\begin{array}{l}\text { negative net assets or non-compliance with } \\
\text { established requirements in relation to net assets; }\end{array}$ & Yes & Tab. 4 \\
\hline 2. & $\begin{array}{l}\text { borrowed funds, the repayment period of which is } \\
\text { approaching, in the absence of a real prospect of } \\
\text { repayment or extension of the loan term, or the } \\
\text { unjustified use of short-term loans to finance } \\
\text { long-term assets; }\end{array}$ & Yes & $\begin{array}{l}\text { As a rule, in the end it is possible to extend } \\
\text { the return period }\end{array}$ \\
\hline 3. & $\begin{array}{l}\text { significant deviation of the values of the main } \\
\text { coefficients characterizing the financial position } \\
\text { of the audited entity from normal (usual) values; }\end{array}$ & Yes & $\begin{array}{l}\text { When calculating the coefficients, industry } \\
\text { indicators were taken into account }\end{array}$ \\
\hline 4. & inability to pay off accounts payable in due time; & Yes & $\begin{array}{l}\text { Lawsuits of counterparties (suppliers and } \\
\text { contractors) to collect overdue debts }\end{array}$ \\
\hline 5. & $\begin{array}{l}\text { failure to provide self-financing for sustainable } \\
\text { business development and other important } \\
\text { investments; }\end{array}$ & Yes & $\begin{array}{l}\text { The inability to form accumulated equity } \\
\text { capital in the presence of negative } \\
\text { performance leads to an increase in } \\
\text { dependence on external sources and } \\
\text { deterioration of financial stability, as well as } \\
\text { to an outflow of investments (decrease in } \\
\text { investment attractiveness) }\end{array}$ \\
\hline 6. & significant losses from core activities; & Yes & $\begin{array}{l}\text { Failure to achieve the set performance } \\
\text { parameters while maintaining the growth rate } \\
\text { and cost structure will contribute to the } \\
\text { preservation of the current inefficiency of } \\
\text { economic activity }\end{array}$ \\
\hline 7. & $\begin{array}{l}\text { difficulties in complying with the terms of the } \\
\text { loan agreement; }\end{array}$ & Yes & $\begin{array}{l}\text { This fact can reduce the company's } \\
\text { creditworthiness, which will lead to } \\
\text { underfunding and increase the risks of } \\
\text { bankruptcy. }\end{array}$ \\
\hline 8. & $\begin{array}{l}\text { arrears in payment or termination of payment of } \\
\text { dividends; }\end{array}$ & No & $\begin{array}{l}\text { Due to negative performance indicators, } \\
\text { dividends were never accrued or paid }\end{array}$ \\
\hline 9. & $\begin{array}{l}\text { signs of bankruptcy established by the legislation } \\
\text { of the Russian Federation; }\end{array}$ & Yes & $\begin{array}{l}\text { According to the assessment of the likelihood } \\
\text { of bankruptcy according to various models, } \\
\text { there is a significant risk of a financial crisis }\end{array}$ \\
\hline II. & Production signs: & & \\
\hline 1. & $\begin{array}{l}\text { The efficiency of economic activity depends } \\
\text { significantly on the successful implementation of } \\
\text { a specific project; }\end{array}$ & Yes & $\begin{array}{l}\text { In the presence of a limited portfolio of } \\
\text { customers and ongoing projects, there is a } \\
\text { significant risk of reduction and non- } \\
\text { fulfillment of performance parameters; } \\
\text { everything will depend on the diversification } \\
\text { of sales channels and the effect of presence } \\
\text { on the market }\end{array}$ \\
\hline III. & Other signs: & & \\
\hline 1. & $\begin{array}{l}\text { lawsuits against the company, which are pending } \\
\text { and may, if the plaintiff succeeds, end with a court } \\
\text { decision that is not feasible for the company; }\end{array}$ & Yes & $\begin{array}{l}\text { Calculation of estimated liabilities for these } \\
\text { lawsuits, assessment of how the presence of } \\
\text { such events will affect the prospective } \\
\text { financial position of the organization }\end{array}$ \\
\hline 2. & $\begin{array}{l}\text { the current macroeconomic (global) and political } \\
\text { situation in the country and in the World, the } \\
\text { presence of intercountry restrictions caused by the } \\
\text { pandemic, the instability of financial markets }\end{array}$ & Yes & $\begin{array}{l}\text { Pandemic COVID-19, slowdown and } \\
\text { disruption of the delivery time of imported } \\
\text { raw materials and equipment, which have no } \\
\text { analogues in the Russian Federation }\end{array}$ \\
\hline
\end{tabular}

The actual efficiency of the business for an external user (existing or potential investor) is disclosed by the company in public information - Accounting (financial) statements for the financial year (BFO).

The fundamental "The going concern in modern approaches assumes that the company will continue its activities in the foreseeable future and it has no intention and the need to liquidate or significantly reduce the scale of its activities. Accordingly, the company will be able to pay off all existing current liabilities on time and ensure current and future financial stability."...[International Financial Reporting Standard (IAS) 1].

Signs that the company will not be able to continue its activities in the foreseeable future (at least a year) can be assessed by the business as ineffective in terms of modern standards for the formation and audit of financial (accounting) statements. This is widely described in the scientific literature and is applied in practice. 
However, in recent years, in our research, we are faced with a rather paradoxical situation when the company has developed all the standard features, quantitative and qualitative, indicating the impossibility of continuing its activities in the foreseeable future (violation of the business continuity assumption), and such an unstable situation continues from one financial period to another. But in spite of everything, the company continues its financial and economic activities. At the same time, a company may have a high reputation in the market as a professional in a particular sector, and it is investment and creditworthy.

Let's consider the situation with a specific example. The company has been operating since 2016. To avoid questions about the bad faith and corruption of the company's management, the company undergoes a government audit and a statutory audit every year, which guarantees the reliability of the financial statements submitted by the organization. Based on the data from the financial statements and economic planning information of the organization, an analysis of the financial indicators of the organization's economic activity for the period 2018 - 2020 was carried out. (tab. 14)

As follows from the data in Table 4, the company has rather ambitious plans, since 2017 it has been a participant in international projects, the implementation of which depends on the financing of customers from the budgets of various levels.

However, if you do not take into account these very specific features, and approach the analysis of the financial performance of the company from the standpoint of the accepted standard approaches (see Fig. 1 of this article), then the system of indicators of the current actual efficiency will take mostly "bad" values, indicating the company's inability to continue operating in the foreseeable future and ineffective management (Table 5).

The calculated liquidity indicators indicate a violation of solvency and characterize the financial condition of the enterprise for the analyzed period as unstable, which indicates the negative actual efficiency of the economic entity and casts doubt on the continuity of its further economic activities.

Thus, our research has shown that despite all the signs of ineffective activity and unstable financial condition according to formally calculated indicators, the company continues to operate in accordance with its strategic plans, occupies a certain market share, has a positive business reputation and trust of creditors and investors. Therefore, questions for further research and scientific discussion:

1. What factors of the company's activity should be taken into account when formalizing calculations for analyzing current and strategic efficiency in order to obtain results that closely correspond to the actual state of affairs in the company.

2. Should the activities of a company with negative performance be viewed as a pyramid effect or as the realities of modern business (today, according to our data, the number of companies with similar financial indicators is growing, which retain their positions in the market for a number of years with negative performance indicators).

3. What system of analytical indicators, ultimately, will adequately assess the economic efficiency in the realities of modern business, taking into account their unstable financial condition.

4. How a possible improved system of analytical indicators will allow relying on the normal values of the calculated indicators.

\section{CONCLUSION}

All these questions point to the controversial nature of the problem of assessing the economic efficiency of the organization's economic activity. The features of accounting and analytical support of strategic efficiency by stages of the life cycle are practically not covered in modern scientific and special literature and require the development of a separate methodology for its assessment and management at the long-term level, which will make it possible to maintain sustainable development of both individual economic entities and the country's economy in the whole. All this determines the relevance and practice-orientedness of the research being conducted.

\section{REFERENCES}

[1] S. A. Boronenkova, M. V. Melnik, A.V. Chepulyanis, Ministry of Education and Science of the Russian Federation, Ural State Economic University, Yekaterinburg: USUE Publishing House, 2017.

[2] N. S. Plaskova, Strategic and Current Economic Analysis: Monograph, 2007, pp. 653.

[3] A. V. Chepulyanis, Theoretical and methodological foundations of strategic accounting and cost analysis: monograph, Yekaterinburg: Publishing house of Ural.un-ta, 2016.

[4] A. Chepulaynis, S. Boronenkova, E3S Web of Conferences, 208 (2020) pp. 03015.

[5] A. Chepulyanis, N. Mokina, I. Vlasova, SHS Web of Conferences, 93 (2021) pp. 02009.

[6] A. V. Chepulyanis, D. A. Endovitskiy, Accounting. Analysis. Audit, 6 (2016). 
[7] E. A. Yakovleva, D. S. Demidenko, Scientific and technical bulletin of SPbSPU. Economic sciences, 3(197) (2014).

[8] N. M. Tyukavin, Audit and financial analysis, 5 (2007).

[9] L. V. Ermolina, Bulletin of SamSU, 10(91) (2011).

[10] V. A. Shabashev, V. B. Batievskaya, Bulletin of SibGAU, 2(54) (2014). 